\title{
Corrigendum
}

\section{Glucose transporter 1-mediated glucose uptake is limiting for B-cell acute lymphoblastic leukemia anabolic metabolism and resistance to apoptosis}

T Liu, RJ Kishton, AN Macintyre, VA Gerriets, H Xiang, X Liu, ED Abel, D Rizzieri, JW Locasale and JC Rathmell

Cell Death and Disease (2014) 5, e1516; doi:10.1038/cddis.2014.493; published online 6 November 2014

Correction to: Cell Death and Disease (2014) 5, e1470; doi:10.1038/cddis.2014.431; published online 16 October 2014

Since the publication of this paper it has been noted that ED Abel's name was incorrect. The corrected article appears online together with this corrigendum.
The authors would like to apologize for any inconvenience for any this may have caused. 